\title{
Implementasi Metode Best First Search untuk Pembelajaran Matematika Berbasis Multimedia Interaktif (Studi kasus: Anak Tunarungu)
}

M.ICHWAN, YOULLIA INDRAWATY N , ANDHIKA PAHLEVI

Jurusan Teknik Informatika. Fakultas Teknologi Industri

Institut Teknologi Nasional

Email: michwan@itenas.ac.id

\begin{abstract}
ABSTRAK
Best first search merupakan sebuah metode pencarian heuristic dengan memilih nilai terbaik dari beberapa data. Metode best first search diimplementasikan untuk pembelajaran perkalian matematika berbasis multimedia interaktif. Pada aplikasi ini best first search digunakan sebagai pengukur nilai waktu terkecil pada data hasil pengujian dengan membandingkan tiga cara perhitungan perkalian. Model skenario multimedia merupakan alur komponen dari awal multimedia hingga multimedia selesai. Sehingga dapat menghasilkan suatu tampilan yang interaktif. Aplikasi ini ditujukan kepada anak tunarungu sebagai alternatif pembelajaran perkalian matematika. Pengujian aplikasi dilakukan kepada 10 responden anak tunarungu dan mendapatkan kesimpulan best first search berhasil mendapatkan nilai waktu terkecil dari cara kedua dengan perolehan nilai 203.
\end{abstract}

Kata Kunci: Algoritma Best First Search, Tunarungu, Matematika, Multimedia Interaktif.

\begin{abstract}
Best first search is a search method that is used to find the deepest values until the desired value is reached. The workings of this method to search the data as much as possible by comparing the value of the most smallest. In this application the best first search method is implemented for learning multiplication math-based interactive multimedia. In this application best first search using as a measure of the smallest time value on the test data by comparing three ways multiplication calculations. Multimedia scenario models a workflow component of multimedia to multimedia finished early. So as to produce an interactive display. This application is intended as an alternative to the deaf children learning math multiplication. Testing the application made to the 10 respondents deaf child and came to the conclusion best first search managed to get the smallest time value of the latter with the acquisition value of 203.
\end{abstract}

Keyword: Best First Search Algorithm, deaf, Mathematics, Multimedia Interactive 


\section{PENDAHULUAN}

Best first search merupakan sebuah metode pencarian heuristic dengan memilih nilai terbaik dari beberapa data. Pencarian best first search dilakukan dengan membuka semua data serta menerapkan fungsi heuristik pada setiap pencarian untuk menghasilkan pengganti data yang telah dibuka. Fungsi heuristik pada best first search merupakan suatu strategi untuk melakukan proses pencarian ruang keadaan suatu masalah secara selektif, yang memandu proses pencarian yang dilakukan sepanjang jalur yang memiliki kemungkinan sukses paling besar. Best first search memilih data biaya terkecil diantara semua data yang pernah dibuka. Penentuan nilai terbaik dilakukan dengan menggunakan sebuah fungsi yang disebut fungsi evaluasi $f(n)$. Fungsi evaluasi best first search dapat berupa nilai yang telah tersimpan dari sebuah data menuju goa/atau gabungan antara nilai sebenarnya dan nilai perkiraan tersebut.

Metode best first search diimplementasikan pada aplikasi pembelajaran perkalian matematika berbasis multimedia interaktif. Pada aplikasi ini best first search digunakan sebagai pengukur nilai waktu terkecil pada data hasil pengujian dengan membandingkan tiga cara perhitungan perkalian. Untuk mendapatkan nilai waktu terkecil dari masing-masing cara dibutuhkan data hasil pengujian pada anak tunarungu. Dari data yang didapatkan best first search melakukan pencarian dengan membuka semua data dan memilih data yang memiliki nilai waktu terkecil. Kemudian best first search membandingkan nilai waktu pada tiga cara tersebut, lalu memutuskan dari pencarian tersebut data dari cara manakah yang memiliki nilai waktu terpendek.

Aplikasi pembelajaran perkalian matematika dapat dimanfaatkan oleh anak tunarungu sebagai media pembelajaran alternatif. Karena pada dasarnya anak tunarungu kecenderungan memiliki permasalahan dalam belajar yang disebabkan oleh kurangnya kemampuan untuk memahami ujaran orang, pengertian yang dikemukakan oleh para ahli tentang pengertian tunarungu salah satunya yaitu menurut Somantri (2007:93). Kondisi ini, sering disebabkan oleh ketidakmampuan dalam penguasaan pendengaran, sehingga akhirnya mereka menghindari aktivitas berbahasa karena pendengarannya terganggu.

Mengenai permasalahan yang telah di jelaskan, disimpulkan bahwa dengan pembelajaran perkalian matematika diharapkan dapat mengoptimalkan kemampuan belajar perkalian matematika anak tunarungu.

\section{METODOLOGI PENELITIAN}

\subsection{Multimedia Interaktif}

Multimedia interaktif adalah adanya penggunya yang diijinkan untuk menampilkan suatu proyek multimedia untuk mengatur apa dan kapan elemen-elemen (teks, grafik, video, animasi, dan audio) ditunjukkan atau ditampilkan. Interaksi antara penyedia jasa dengan pemakai, menghasilkan komunikasi dua arah karena sifat komputer dapat deprogram, sehingga pengendalian kerja sistem dapat diuba-ubah [3].

\subsection{Algoritma Best First Search}

Best-First Search merupakan sebuah metode pencarian data dengan menerapkan nilai heuristic. Penentuan data terbaik dilakukan dengan menggunakan sebuah fungsi yang disebut fungsi evaluasi. fungsi evaluasi best-first search dapat berupa biaya perkiraan dari suatu data terpilih menuju ke goa/atau gabungan antara biaya sebenarnya dan biaya perkiraan tersebut [4]. 
Implementasi Metode Best First Search untuk Pembelajaran Matematika Berbasis Multimedia Interaktif (Studi kasus: Anak Tunarungu)

Persamaan (1) perhitungan best first search :

$$
f(n)=h(n)
$$

- $\quad F(n)$ : fungsi nilai evaluasi.

- $H(n)$ : fungsi nilai heuristik data.

\subsection{Storyline}

Berikut ini merupakan storyline dari aplikasi pembelajaran perkalian matematika.

\section{Tampilan Pembuka}

Scene 1 (movie clip, suara, dan teks) : Muncul tampilan pembuka yang berisi animasi, backsound, dan teks ucapan selamat datang aplikasi secara bersamaan..

\section{Tampilan Loading}

Scene 1 (movie clip, suara, dan teks) : Muncul tampilan loading yang berisi animasi, backsound, dan teks judul aplikasi secara bersamaan.

\section{Tampilan Dari Menu Utama}

Scene 1 (movie clip, suara, dan teks) : Pengguna memilih salah satu menu, yaitu menu bermain perkalian, menu belajar perkalian, dan menu peraturan aplikasi.

Scene 2 (movie clip, suara, dan teks) : Pengguna memilih menu bermain perkalian, tampilan akan berpindah ke tampilan bermain perkalian.

Scene 3 (movie clip, suara, dan teks) : Pengguna memilih menu belajar perkalian, tampilan akan berpindah ke tampilan belajar perkalian.

Scene 4 (movie clip, suara, dan teks) : Pengguna memilih menu peratura aplikasi, tampilan akan berpindah ke tampilan peraturan aplikasi.

\section{Tampilan Biodata Siswa}

Scene1 (movie clip, suara, dan teks) : Pengguna memasukan nama pada teks dynamic nama.

Scene 2 (movie clip, suara, dan teks) : Teks dynamic keterangan akan menuliskan "Harap Kolom Nama Diisi Terlebih Dahulu" apabila pengguna tidak mengisi kolom nama.

Scene 3 (movie clip, suara, dan teks) : Pengguna akan menekan tombol enter setelah melakukan pengisian data pada kolom nama dan berpindah ke tampilan bermain perkalian cara-1.

\section{Tampilan Pilihan Cara Belajar}

Scene 1 (movie clip, suara, dan teks) : Pengguna memilih salah satu menu cara, yaitu menu cara-1, menu cara-2, dan menu cara-3.

Scene 2 (movie clip, suara, dan teks) : Pengguna memilih menu cara-1, tampilan akan berpindah ke tampilan belajar cara-1.

Scene 3 (movie clip, suara, dan teks) : Pengguna memilih menu cara-2, tampilan akan berpindah ke tampilan belajar cara-3.

\section{Tampilan Peraturan Aplikasi}

Scene 1 (movie clip, suara, dan teks) : Pengguna akan ditampilkan teks static yang berisikan poin-poin apa saja yang harus diikuti pengguna dalam menggunakan aplikasi ini.

\section{Tampilan Belajar Cara-1}

Scene 1 (movie clip, suara, dan teks) : Pengguna akan ditampilkan teks dynamic yang berisikan tentang proses perhitungan perkalian dari cara-1. 


\section{Tampilan Belajar Cara-2}

Scene 1 (movie clip, suara, dan teks) : Pengguna akan ditampilkan teks dynamic yang berisikan tentang proses perhitungan perkalian dari cara-2.

\section{Tampilan Belajar Cara-3}

Scene 1 (movie clip, suara, dan teks) : Pengguna akan ditampilkan teks dynamic yang berisikan tentang proses perhitungan perkalian dari cara-3.

\section{Tampilan Bermain Cara-1}

Scene 1 (movie clip, suara, dan teks) : Pengguna akan ditampilkan pertanyaan perkalian dari cara-1.

Scene 2 (movie clip, suara, dan teks) : Muncul teks static cara ke berapa, no soal ke berapa, teks dynamic nama siswa, teks static langkah, dan teks dynamic waktu.

11. Tampilan Bermain Cara-2

Scene 1 (movie clip, suara, dan teks) : Pengguna akan ditampilkan pertanyaan perkalian dari cara-2.

Scene 2 (movie clip, suara, dan teks) : Muncul teks static cara ke berapa, no soal ke berapa, teks dynamic nama siswa, teks static langkah, dan teks dynamic waktu.

\section{Tampilan Bermain Cara-3}

Scene 1 (movie clip, suara, dan teks) : Pengguna akan ditampilkan pertanyaan perkalian dari cara-3.

Scene 2 (movie clip, suara, dan teks) : Muncul teks static cara ke berapa, no soal ke berapa, teks dynamic nama siswa, teks static langkah, dan teks dynamic waktu.

\subsection{Storyboard}

Pada Tabel 1 merupakan storyboard dari aplikasi pembelajaran perkalian matematika.

\section{Tabel 1. Storyboard aplikasi}

\begin{tabular}{|l|c|l|}
\hline No & Ilustrasi & \multicolumn{1}{c|}{ Keterangan } \\
\hline & & $\begin{array}{l}\text { Tampilan pembuka, terdiri dari : } \\
\text { - Kata pembuka aplikasi } \\
\text { - Animasi kata pembuka }\end{array}$ \\
\hline 2 & & $\begin{array}{l}\text { Tampilan loading, terdiri dari : } \\
\text { - Kotak loading intro } \\
\text { - Teks static tampilan loading } \\
\text { - Animasi }\end{array}$ \\
\hline
\end{tabular}


Implementasi Metode Best First Search untuk Pembelajaran Matematika Berbasis Multimedia Interaktif (Studi kasus: Anak Tunarungu)

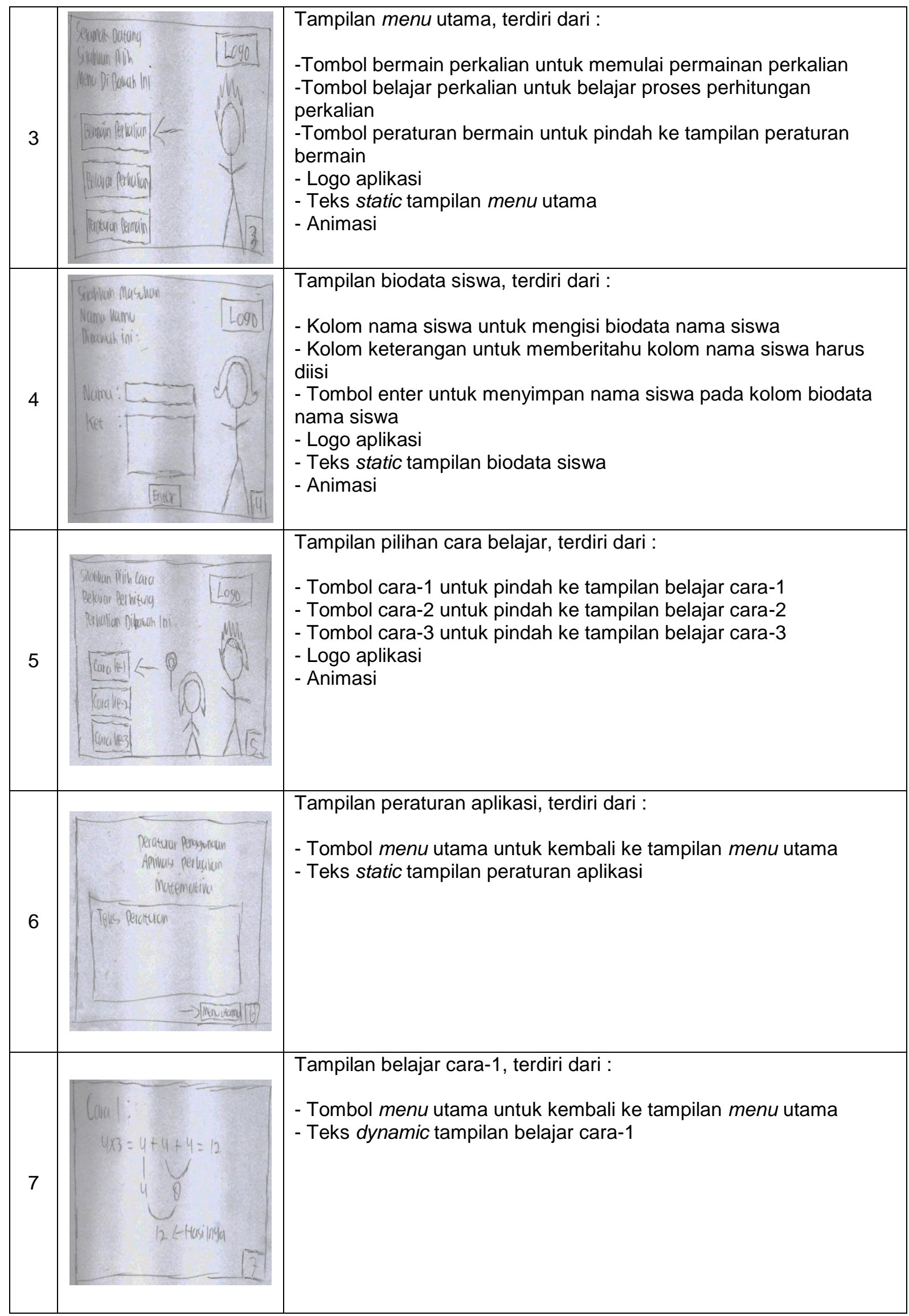




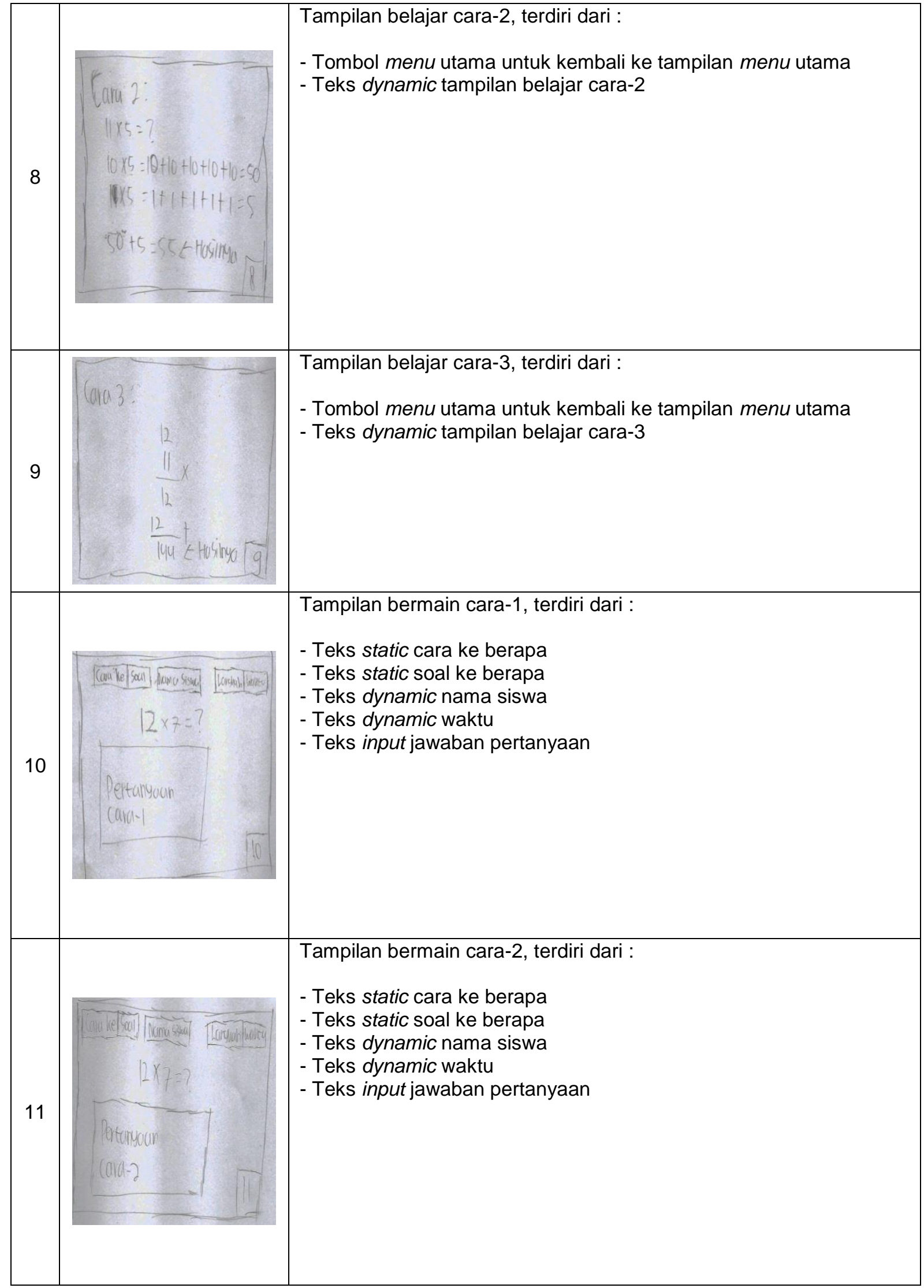


Implementasi Metode Best First Search untuk Pembelajaran Matematika Berbasis Multimedia Interaktif (Studi kasus: Anak Tunarungu)

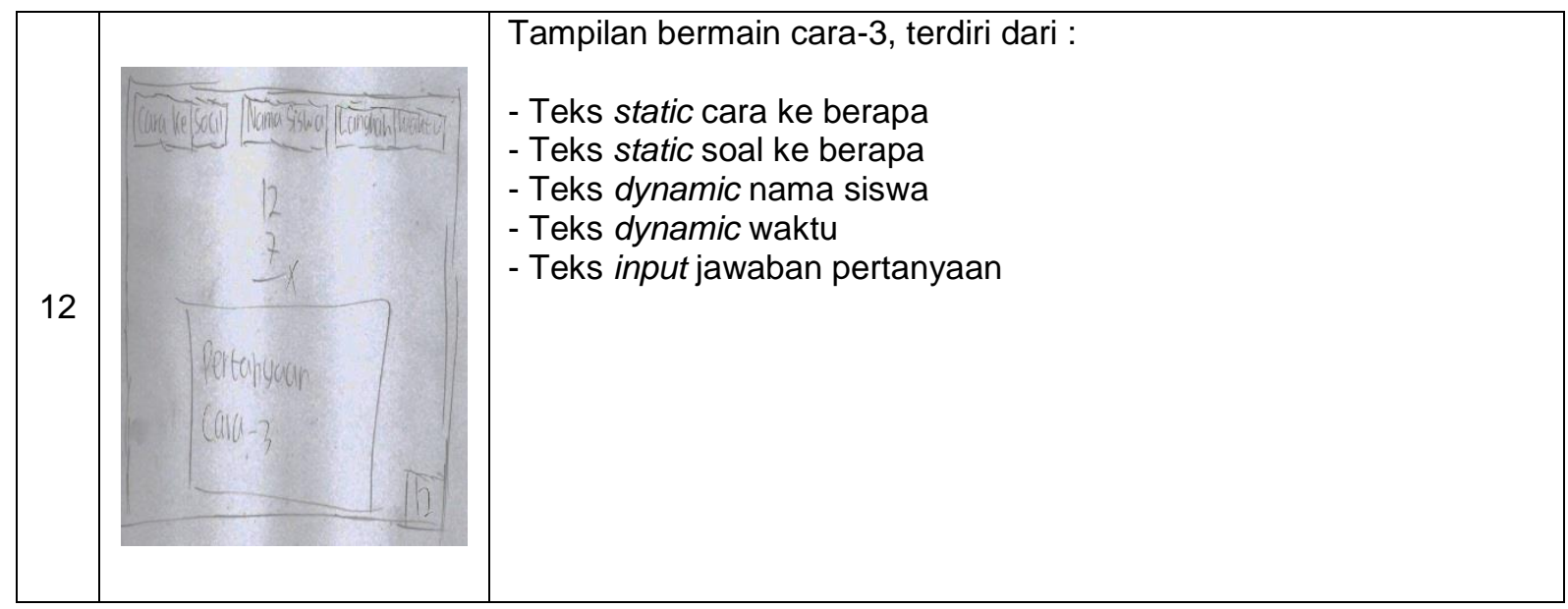

\subsection{Proses Best First Search}

Pada Gambar 4 merupakan alur proses dari proses perhitungan waktu berdasarkan best first search. Waktu yang didapatkan dari hasil pengujian disimpan dan diseleksi menurut nilai waktu terendah.

Ada beberapa istilah yang sering digunakan pada metode best-first search, diantaranya:

- Open adalah list yang digunakan untuk menyimpan data yang pernah diaktifkan dan nilai heuristiknya telah dihitung tetapi belum terpilih sebagai data terbaik (best node) atau biasa disebut dengan initial state.

- Evaluate adalah proses untuk memeriksa data.

- Closed adalah list yang digunakan untuk menyimpan data yang tidak mungkin terpilih sebagai data terbaik (peluang terpilih tertutup.

- Goaladalah tujuan akhir dari pencarian.

Pada Gambar 5 merupakan salah satu pohon kebenaran algoritma best first search :

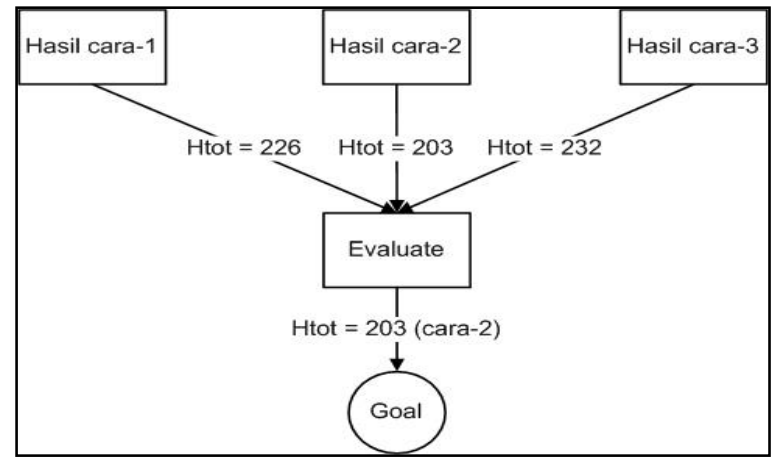

Gambar 1. Contoh kasus best first search

Dibawah ini merupakan langkah-langkah proses pencarian best first search pada Gambar 1. 
Langkah 1 :

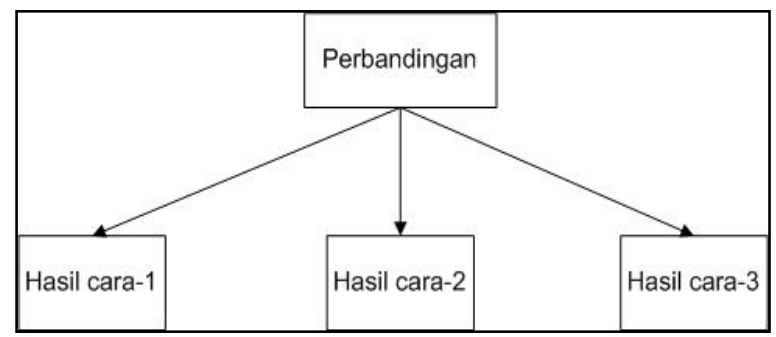

\section{Gambar 2. Langkah 1 pencarian best first search}

Pada Gambar 2 merupakan langkah satu pencarian nilai waktu dari data hasil cara-1, hasil cara-2, dan hasil cara-3.

Langkah 2 :

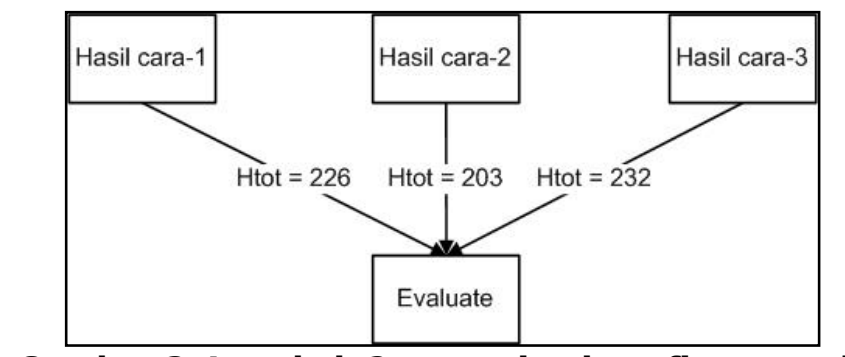

Gambar 3. Langkah 2 pencarian best first search

Pada Gambar 3 merupakan langkah dua pencarian best first search dari ketiga hasil yang sudah memiliki nilai heuristic total, yaitu hasil cara-1 (Htotal $=226)$, hasil cara-2 (Htotal = 203), dan hasil cara-3 (Htotal =232).

Langkah 3 :

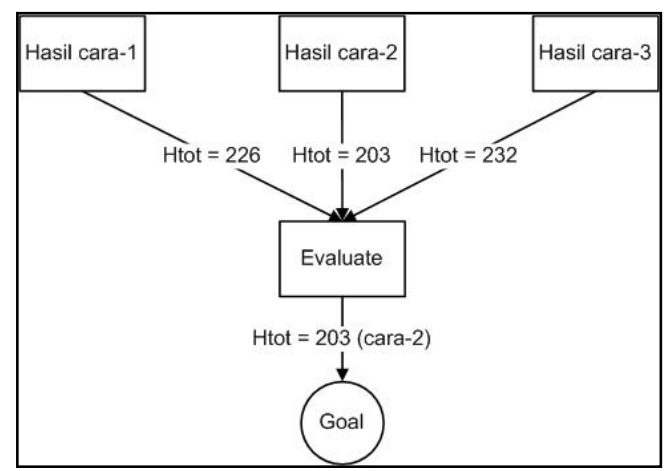

\section{Gambar 4. Langkah 3 pencarian best first search}

Pada Gambar 4 merupakan hasil dari pencarian metode best first search ditinjau dari nilai Htotall terkecil adalah cara-2 dengan nilai 203.

Berikut ini adalah contoh pseudocode pencarian best first search. Seperti Gambar 6.

1. OPEN = [Perbandingan $] ;$ CLOSED $=[]$;

2. EVALUATE $=$ [Perbandingan $] ;$ OPEN $=$ [Hasil cara-1, Hasil cara-2, Hasil cara-3]; CLOSED = [Perbandingan $] ;$

3. $\mathrm{GOAL}=[$ Hasil cara-2]; 


\subsection{Model Skenario Multimedia Interaktif Menggunakan firefly}

Model skenario yang digunakan pada pembangunan aplikasi ini adalah model firefly. Model firefly merupakan model skenario multimedia yang bentuknya menyerupai kunang-kunang. Pada Gambar 5 merupakan alah satu contoh penggunaan skenario firefly.

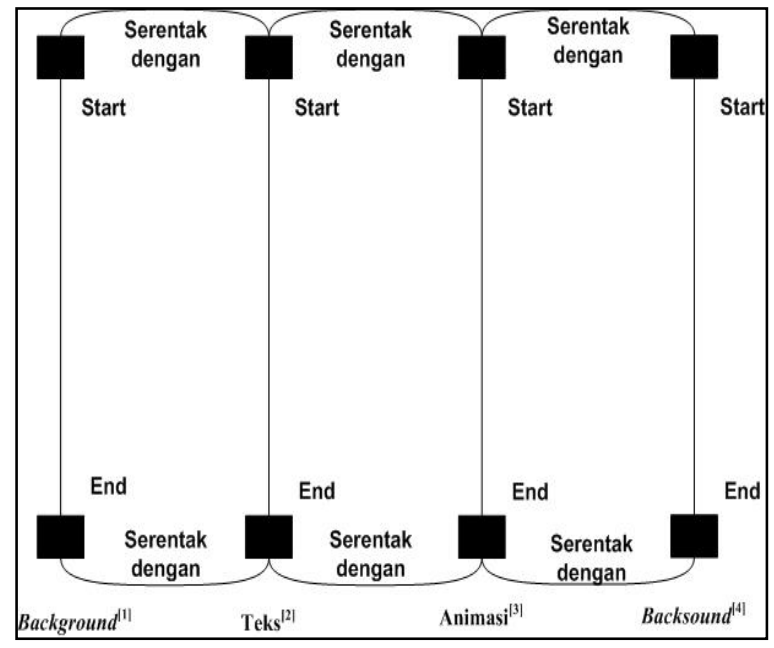

Gambar 5. Firefly Tampilan Awal

\section{ANALISIS DAN PEMBAHASAN}

Implementasi dilakukan dalam dua tahap, yaitu implementasi Graphic User Interface (GUI) dan implementasi program sesuai dengan perancangan pada bab analisis dan perancangan. Dengan melakukan tahap ini perancangan dan hasil uji dapat selaras dan sesuai dengan tujuan dibuat aplikasi.

\subsection{Tampilan Aplikasi}

Tampilan aplikasi merupakan antarmuka yang ditampilkan pada Gambar 6 layer kedua dari aplikasi multimedia interaktif perkalian matematika. Pada layer ini berisi audio, movie clip, graphic dan suara.

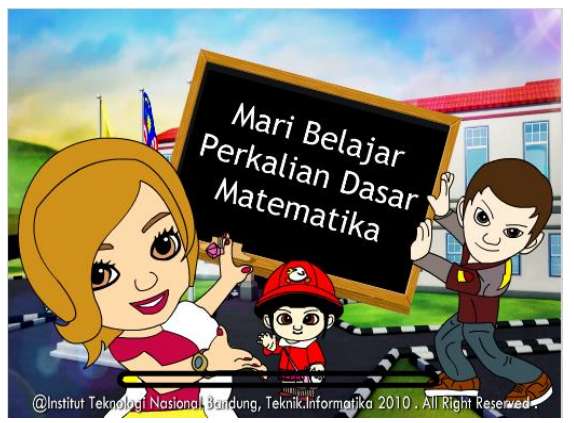

Gambar 6. Tampilan loading aplikasi multimedia interaktif perkalian matematika

Gambar 7 merupakan tampilan dari Joystick (controller) yang sudah terpasang kepada PC. Pada Joystick (controller) terdapat input tombol angka dimulai dari $0 \mathrm{~s} / \mathrm{d}$ 9, tombol eksekutor yaitu tombol enter, tombol delete dan tombol kembali ke menu utama, tombol kursor yaitu tombol kursor atas dan tombol kursor bawah, kemudia juga terdapat dua bagian led yaitu lampu led berwarna merah dan berwarna hijau. Kedua lampu led ini berfungsi sebagai warning kepada pengguna. 


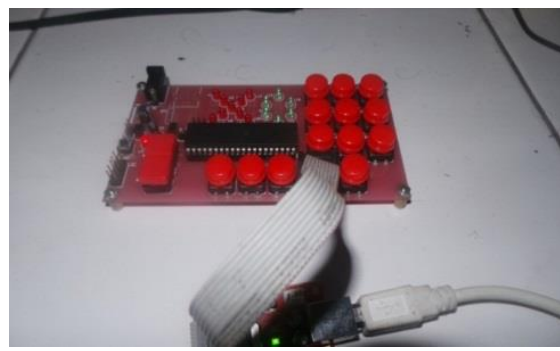

Gambar 7. Perangkat Keras yang digunakan

Halaman bermain perkalian seperti Gambar 8 menampilkan sebuah pertanyaan, berbagai kolom kosong, kolom cara, kolom no soal, kolom nama siswa dan kolom waktu. Kolom kosong digunakan untuk mengisi jawaban soal dari pengguna. Kolom cara digunakan untuk menampilkan cara ke berapa pengguna sedang menjawab pertanyaan tersebut. Kolom no soal digunakan untuk menampilkan pengguna sedang mengerjakan pertanyaan no berapa. Kolom siswa digunakan untuk menampilkan nama siswa tunarungu yang sedang mengerjakan pertanyaan tersebut. Dan kolow waktu berperan untuk menghitung berapa lama pengguna mengerjakan pertanyaan yang disajikan.

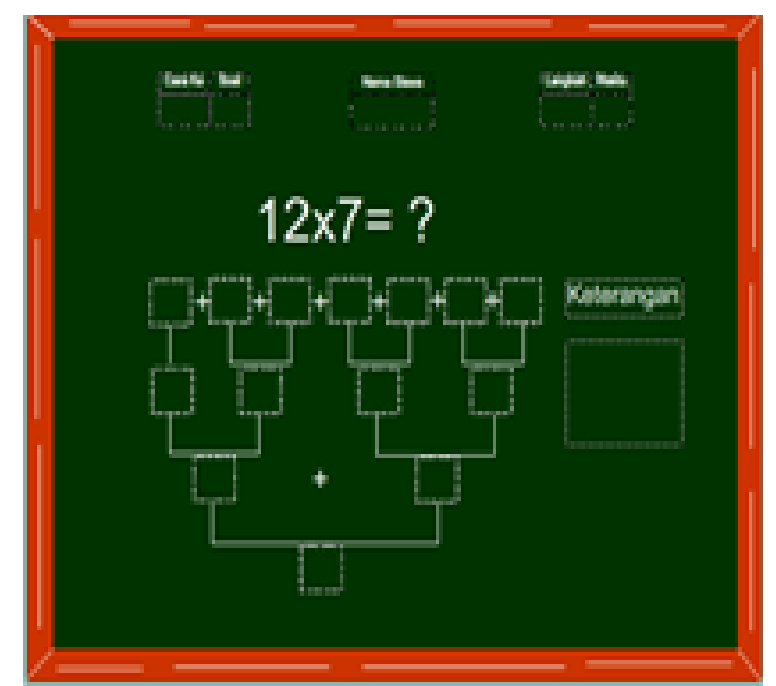

\subsection{Hasil Pengujian}

Gambar 12 Halaman bermain perkalian

Pengujian ini dilakukan dengan menguji interaksi aplikasi dan pengguna. Jumlah pengguna dalam pengujian ini adalah lima orang siswa SDLB kelas enam. Adapun hasil pengujian yang di tampilkan dari 10 orang responden anak tunarungu yang diuji. 
Implementasi Metode Best First Search untuk Pembelajaran Matematika Berbasis Multimedia Interaktif (Studi kasus: Anak Tunarungu)

Tabel 2. Pengujian interaksi aplikasi dan pengguna tunarungu

\begin{tabular}{|c|c|c|c|}
\hline $\begin{array}{l}\text { Nama } \\
\text { Siswa }\end{array}$ & Cara & Langkah & Waktu \\
\hline \multirow{3}{*}{ Salma } & Cara-1 & 79 & 253 \\
\hline & Cara-2 & 72 & 244 \\
\hline & Cara-3 & 5 & 255 \\
\hline \multirow[t]{3}{*}{ Rizky David } & Cara-1 & 79 & 282 \\
\hline & Cara-2 & 72 & 235 \\
\hline & Cara-3 & 5 & 265 \\
\hline \multirow{3}{*}{$\begin{array}{c}\text { Adinda } \\
\text { Khaerunisa }\end{array}$} & Cara-1 & 79 & 251 \\
\hline & Cara-2 & 72 & 225 \\
\hline & Cara-3 & 5 & 233 \\
\hline \multirow{3}{*}{$\begin{array}{l}\text { Ario Nur } \\
\text { Ramadhan }\end{array}$} & Cara-1 & 79 & 254 \\
\hline & Cara-2 & 72 & 232 \\
\hline & Cara-3 & 5 & 234 \\
\hline \multirow{3}{*}{$\begin{array}{c}\text { Iqbal } \\
\text { Prasetyo }\end{array}$} & Cara-1 & 79 & 310 \\
\hline & Cara-2 & 72 & 248 \\
\hline & Cara-3 & 5 & 250 \\
\hline \multirow[t]{3}{*}{ Mario } & Cara-1 & 79 & 343 \\
\hline & Cara-2 & 72 & 262 \\
\hline & Cara-3 & 5 & 280 \\
\hline \multirow{3}{*}{$\begin{array}{c}\text { Reza Novia } \\
P\end{array}$} & Cara-1 & 79 & 306 \\
\hline & Cara-2 & 72 & 281 \\
\hline & Cara-3 & 5 & 308 \\
\hline \multirow[t]{3}{*}{ Rio } & Cara-1 & 79 & 291 \\
\hline & Cara-2 & 72 & 298 \\
\hline & Cara-3 & 5 & 322 \\
\hline \multirow[t]{3}{*}{ Syifa } & Cara-1 & 79 & 344 \\
\hline & Cara-2 & 72 & 267 \\
\hline & Cara-3 & 5 & 354 \\
\hline \multirow[t]{3}{*}{ Andika } & Cara-1 & 79 & 343 \\
\hline & Cara-2 & 72 & 279 \\
\hline & Cara-3 & 5 & 310 \\
\hline
\end{tabular}

Pada Tabel 3 merupakan hasil perhitungan nilai waktu terpendek menggunakan best first search yang ditinjau dari cara-1. Sebagai berikut.

Tabel 3. Hasil perhitungan nilai waktu terpendek dengan cara-1

\begin{tabular}{|c|c|c|}
\hline No & Nama Siswa & Waktu \\
\hline 1 & Rizky & 38 \\
\hline 2 & Adinda & 42 \\
\hline 3 & Salma & 62 \\
\hline 4 & Rizky & 43 \\
\hline 5 & Ario & 41 \\
\hline \multicolumn{2}{|c|}{ Total Nilai Waktu Cara-1 } & 226 \\
\hline
\end{tabular}

Pada Tabel 4 merupakan hasil perhitungan nilai waktu terpendek menggunakan best first search yang ditinjau dari cara-2. Sebagai berikut.

Tabel 4. Hasil perhitungan nilai waktu terpendek dengan cara-2

\begin{tabular}{|c|c|c|}
\hline No & Nama Siswa & Waktu \\
\hline 1 & Rizky & 41 \\
\hline 2 & Adinda & 36 \\
\hline 3 & Salma & 41 \\
\hline 4 & Rizky & 41 \\
\hline 5 & Ario & 37 \\
\hline \multicolumn{2}{|c|}{ Total Nilai Waktu Cara-2 } & 206 \\
\hline
\end{tabular}


Pada Tabel 5 merupakan hasil perhitungan nilai waktu terpendek menggunakan best first search yang ditinjau dari cara-3. Sebagai berikut.

Tabel 5. Hasil perhitungan nilai waktu terpendek dengan cara-3

\begin{tabular}{|c|c|c|}
\hline No & Nama Siswa & Waktu \\
\hline 1 & Ario & 40 \\
\hline 2 & Rizky & 44 \\
\hline 3 & Ario & 53 \\
\hline 4 & lqbal & 44 \\
\hline 5 & Iqbal & 42 \\
\hline \multicolumn{2}{|c|}{ Total Nilai Waktu Cara-3 } & 232 \\
\hline
\end{tabular}

Pada Tabel 6 merupakan hasil perhitungan nilai waktu terpendek menggunakan best first search dengan membandingkan hasil waktu ketiga cara. Sebagai berikut.

Tabel 6. Hasil seleksi sistem best first search

\begin{tabular}{|c|c|c|}
\hline No & Cara & Waktu \\
\hline 1 & Cara-1 & 226 \\
\hline 2 & Cara-2 & 203 \\
\hline 3 & Cara-3 & 232 \\
\hline \multicolumn{2}{|c|}{ Cara terbaik } & $\begin{array}{c}203 \text { (Cara- } \\
\text { 2) }\end{array}$ \\
\hline
\end{tabular}

Berdasarkan Tabel 2 Tingkat keberhasilan aplikasi terhadap anak tunarungu adalah 150 kali dari 225 kali pengujian, dengan persentase sebesar $(100 / 225) * 150=66,6 \%$

Rata-rata poin kesesuaian :

Rata-rata = (jumlah poin waktu) $/$ jumlah pengujian cara.

Jumlah pengujian cara $=3$

- Cara-1

$=(253+282+251+254+310+343+306+291+344+343) / 10$

$=2977 / 10=297,7$

- Cara-2

$=(244+235+225+232+248+262+281+298+267+279) / 10$

$=2571 / 10=257,1$

- Cara-3

$=(255+265+233+234+250+280+308+322+354+310) / 10$

$=2811 / 10=281,1$

\section{KESIMPULAN}

Berdasarkan hasil penelitian yang telah dilakukan dapat diambil kesimpulan bahwa.

1. Berdasarkan Tabel 2 hingga Tabel 6 maka dapat disimpulkan bahwa Algoritma Best First Search telah berhasil mendapatkan nilai waktu terpendek dari hasil pengujian terkecil 10 responden anak tunarungu, yaitu cara kedua dengan perolehan nilai 203.

2. Merujuk pada hasil pengujian beta yang dilakukan oleh 10 orang anak tunarungu terdapat kekurangan pada aplikasi, yaitu $66,6 \%$ dari guru yang melihat pengujian 
Implementasi Metode Best First Search untuk Pembelajaran Matematika Berbasis Multimedia Interaktif (Studi kasus: Anak Tunarungu)

kepada anak tunarungu tampilan masih kurang kata-kata pembimbing didalam aplikasi, serta tampilan yang ditayangkan harus lebih bertemakan tentang anak-anak.

3. Pembuatan aplikasi multimedia interaktif pembelajaran perkalian matematika berhasil dibuat. Semua fitur didalam aplikasi berjalan dengan lancar.

\section{DAFTAR RUJUKAN}

[1] Indrawaty, Youllia. 2011. Materi Kuliah Teknik Multimedia :Teknik Multimedia. Institut Teknologi N.asional : Bandung (tidak dipublikasi).

[2] Prananta, Ari Rudy. 2011. Aplikasi Pencarian Rute Optimum Pada Peta Guna Meningkatkan

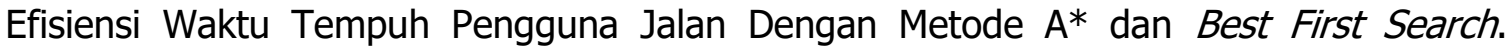
Universitas Kristen Petra : Surabaya

[3] Samsul Kosasi. (2015). Objek Multimedia. From https:// samsulkosasi.wordpress.com/2015/04/09/6-jenis-objek-multimedia/.

[4] Amalia Deisy. (2012). Pengertian Best First Search. From http://deisyamalia.blogspot.co.id/2012/03/best-first-search.html. 